\title{
The Impact of Firm Specific Characteristics on The Relation Between Financial Distress And Capital Structure Decisions
}

\section{Nida ABDİOĞLU iDa}

a Bandırma On Yedi Eylül University, Faculty of Economics and Administration Sciences, Balıkesir, Turkey. nidaabdioglu@yahoo.com

\begin{tabular}{ll}
\hline ARTICLE INFO & ABSTRACT \\
\hline $\begin{array}{l}\text { Keywords: } \\
\text { Capital Structure }\end{array}$ & $\begin{array}{l}\text { Purpose - This study investigates the effect of some of the firm level variables on the relation } \\
\text { between financial distress and capital structure decisions. } \\
\text { Financial Distress } \\
\text { Borsa Istanbul } \\
\text { Panel Data }\end{array}$ \\
& $\begin{array}{l}\text { Design/ methodology/approach - The manufacturing firms listed in Turkish market between } \\
\text { Findings - Financial distress level increases as leverage and short-term debt maturity usage } \\
\text { increase. Firm size, return on equity, asset tangibility variables are reported as effective on the } \\
\text { association between leverage and financial distress. Return on equity and asset tangibility have }\end{array}$ \\
impacts on the relation between financial distress and debt maturity. \\
Revised 30 May 2019 \\
Accepted 18 May 2019
\end{tabular}

\section{Introduction}

Financial distress arises when companies do not have ability to meet their financial obligations (Pindado et al., 2008: 997). Through direct and indirect costs of bankruptcy process, financial distress has a remarkable impact in operations and profitability of firms ${ }^{1}$. Furthermore, financial distress might occur as a result of macro or firm specific factors. Economic recessions, implemantion of tight monetary policy, the decrease in the stock market index are some of the macro factors that increase the probability of financial failure. In addition, manufacturing defect, unsuccessful projects, the problems between employee and employer, higher level of leverage and overgrowth are among the firm specific factors that affect financial failure (Aktas et al., 2003). Although the macro factors can not be avoided, the firm specific factors can be determined and avoided by the managers. As a result, the determination of factors that affect financial distress has become an important topic (Ayan and Degirmenci, 2018).

The existing literature widely examines the determinants of financial distress. Most of them focus on developed economies. There are only a few studies which consider the relation between debt usage and financial distress in developing markets. Differences in market structure, in implemantation of law standars and in implemantation of accounting standards' result in difficulties in application of developed-economic forecast models in emerging countries (Zulkarnain and Shamsher, 2004). In this study, the relation between debt usage and financial distress is considered for an emerging market: Turkey. Capital structure variables are the central focus of this study as the factors affect financial distress. The relation between financial

\footnotetext{
${ }^{1}$ Administrative and legal costs are examples of direct costs while costs of customers and suppliers are among the indirect costs (Lee et al., 2011). 
distress and capital structure mostly is in line with the trade-off theory. Myers' (1977) trade-off theory points out that an ideal capital structure should be determined by the firms. Although using debt gives tax advantages to the corporations, higher amounts of debt results in financial distress risk. A value maximising firm should determine an optimal equity and debt level that balances the gains and losses of the debt.

Although prior researches have investigated the relation between financial distress and capital structure, they have not examined whether firm specific characteristics have any effect on this relation. This paper argues that those firm specific characteristics should have impact on this relation. Firstly, the impact of capital structure on financial distress is investigated among the manufacturing industry firms in Turkish market between the years 2007 and 2017. Secondly, the impact of some of the firm characteristics on the relation between capital structure decisions and financial distress is reported. Those firm features are chosen following related literature and determined as firm size, asset tangibility, market-to-book ratio, sales growth rate and returm on equity.

The paper is structured as follows. Related literature review is provided in section 2. Section 3 includes data and methodology. The empirical results exist in section 4 and finally conclusion of the paper is in section.

\section{Literature Review}

Turaboglu et al. (2017) analysis the relation between financial distress and capital structure decisions. They consider Borsa Istanbul 100 (BIST 100) firms. Altman Z Score and Springate S Score are used to measure financial distress and negative relation is found between financial distress variables and capital structure variables. As short-term debt ratio increases, financial distress increases and therefore financial failure score decreases. In addition, they find that as firm size and fixed asset ratios in a firm increase, financial failure score increases. They show the negative association between financial failure score and external equity ratio consistent with the Pecking Order Theory. They also report that the positive relation between financial distress and debt ratio is in consistent with Trade-off Theory. On the other hand, Akpinar and Akpinar (2017) examine the factors that affect the financial distress risk of Turkish firms. They consider Turkish manufacturing firms traded on Borsa Istanbul for the period 2010-2014. They measure financial distress risk by modified Altman's Z Score. They report that as leverage, size and dividend payment increase, financial distress risk increases (z score decreases). In contrast, profitability, firm age, firm value and intellectual capital negatively affect financial distress risk.

Muigai and Muriithi (2017) investigate how firm size affects the relation between financial distress and capital structure of Kenyan firms. A significant impact of firm size is found on the relation between financial distress and capital structure. Although higher level of debt causes an increase in the financial distress level, large firms have abilities to use more debt and reduce the financial distress possibility. They also prove that while long term debt positively affects large firms, short term debt negatively affects them. Therefore, they conclude that the firms should consider the firm size in making capital structure choices. In addition, Muigai and Mutiso (2018) examine how effective the sectors of the Kenyan companies on the relation between financial distress and capital structure decisions. They report that sectors of those companies significantly affect the relation between financial distress and capital structure choices. Moreover, Lee et al. (2011) investigate how the relation between financial distress and leverage is affected by capital intensity for United States restaurant firms. According to their results, while financial distress increases by increased leverage it decreases by increased capital intensity. As the firms' capital intensity increase, the leverage's effect on financial distress reduces (Lee et al., p. 435).

The important part of the financial distress literature consists of the studies which investigate the impact of firm characteristics on financial distress probability. Among those studies Hadlock and James (2002) and Chancharat (2008) find that leverage positively affects financial distress probability. Umar et al. (2012) and Gupta et al. (2014) also find that leverage negatively affects financial distress. Tim et al. (2011) examine the impact of firm characteristics on financial distress levels of the firms in Bursa Malaysia. Firm size and interest coverage ratio positively affect financial distress, whereas growth of operating profits negatively affects financial distress. Terzi (2011) find asset profitability and debt/equity proportion as effective on 
financial distress of companies. In addition, he reports that profitability, financial structure and operating effectiveness are effective in shaping financial distress of Turkish companies.

Lastly, another part of the financial distress literatue investigate the relation between firm performance and financial distress. By using sales growth and market share as proxies of firm performance, Opler and Titman (1994) find that financial distress negatively affects firm performance. Tan (2012) examine the role of financial distress on firm performance of East Asian economies during Asian Financial Crisis of 1997-1998. He uses leverage as a proxy for financial distress. He reports that low leveraged firms perform better than high leveraged firms. In addition, the crisis strengthens this negative relation between financial distress and firm performance. Thus, the companies with higher level of leverage show worse performance during crisis. Ege et al. (2017) use Fulmer H-Score as a measure for financial distress and investigate the relation between financial distress and firm performance. They consider the manufacturing firms in Borsa Istanbul 100 indices. They report that Fulmer H-Score positively affects firm performance of Turkish firms. Therefore, they conclude that as financial distress levels of the firms decrease, the financial performance of the firms increases. Ozcalik and Aytekin (2018) investigate the relation between financial distress and financial performance for the firms listed in Borsa Istanbul Non-Metal Mineral Product Index (XTAST) for the period 2009-2016. Fulmer H-Score is used to measure financial distress. A positive relation is found between firm performance and Fulmer H-Score.

\section{Data and Methodology}

This paper investigates the role of firm characteristics on the relation between financial distress and capital structure for the manufacturing industry firms listed in Turkish market for the period 2007-2017. Finnet database is used in order to collect related data. Firm- years missing values are excluded and finally the panel consists of 1800 firm- years observations.

Firm fixed effect panel regressions are used in the study in order to account for firm level omitted variables which are time- invariant. Year dummies are also added into the regression to control for cross- sectional dependence (Gujarati, 2004). In addition, time series dependence is controlled by using heteroskedasticity robust standard errors in all regressions by clustering them at the firm level.

Following regressions are used in this paper:

$$
\begin{aligned}
& Z \text { Score }=a_{0}+a_{1} \text { lev }+a_{2} \text { LTdebt }+a_{3} \text { Tang }+a_{4} \text { Size }+a_{5} \text { Salesgr }+a_{6} M B+a_{7} R O E+Y D(1) \\
& \text { SScore }=a_{0}+a_{1} \text { lev }+a_{2} \text { LTdebt }+a_{3} \text { Tang }+a_{4} \text { Size }+a_{5} \text { Salesgr }+a_{6} M B+a_{7} \text { ROE }+Y D(2) \\
& Z S \text { core }=a_{0}+a_{1} \text { lev }+a_{2} \text { STdebt }+a_{3} \text { Tang }+a_{4} \text { Size }+a_{5} \text { Salesgr }+a_{6} M B+a_{7} R O E+Y D(3) \\
& \text { SScore }=a_{0}+a_{1} \text { lev }+a_{2} \text { STdebt }+a_{3} \text { Tang }+a_{4} \text { Size }+a_{5} \text { Salesgr }+a_{6} M B+a_{7} R O E+Y D(4)
\end{aligned}
$$

ZScore is Altman's Z Score and SScore is Springate S Score. Lev is leverage ratio, LTdebt is long term debt ratio, STdebt is short term debt ratio, Tang is tangibility, Size is firm size, Salesgr is sales growth rate, MB s market-to-book ratio, ROE is return on equity and YD is year dummies. The definition of these variables are as follows:

Financial Distress: Altman's Z Score and Springate S Score are used in order to measure financial distress of the selected firms in this paper. Altman (1968) defines $Z$ Score as follows:

$Z$ score $=1.2^{*} X 1+1.4^{*} X 2+3.3^{*} X 3+0.6^{*} X 4+1.0^{*} X 5$

where $X 1=$ Net working capital/Total assets,

$\mathrm{X} 2$ = Retained earnings/Total assets,

X3 = Earnings before Interest and Taxes/Total Assets,

X4 = Market value of equity/Book value of total liabilities,

X5 $=$ Net Sales $/$ Total Assets

If a firm has $Z$ Score which is equal to 2.7 or higher than 2.7, this firm is in safe and the probability of financial distress and bankruptcy is lower. If $Z$ Score is lower than 1.8, probability of bankruptcy and 
financial distress is higher. If $\mathrm{Z}$ Score is between 1.8 and 2.7, the firm is at risk of going bankrupt unless an action is taken to survive.

Second financial distress indicator is Springate $S$ Score which is defined as follows:

S Score $=1,03^{*} X 1+3,07^{*} X 2+0,66^{*} X 3+0,4^{*} X 4$

where

X1 $=$ Working capital/Total assets,

$\mathrm{X} 2$ = Earnings before Interest and Taxes/Total Assets,

X3 = Earnings before taxes/ short term liabilities,

X4= Sales/ Total Assets

If $\mathrm{S}$ Score of a firm is below 0.862 , the probability of financial distress and bankruptcy is higher. However, if $\mathrm{S}$ Score is above 0.862 , financial distress probability is lower.

Leverage: Leverage is the ratio of total debt to total assets. According to Berger and Di Patti (2006), debt level positively affects corporate financial distress in the US banking industry. However, Pushner (1995) report that debt level of Japanese firms negatively affects financial distress. Brealey and Myers (1984) accept highly leveraged firms as risky firms because of the implicit and explit costs associated with their financial distress (Lee et al., 2011). According to Brealey and Myers (1984), Mandelker and Rhee (1984), as leverage increases firm risk increases as well. In addition, Peterson's (1994) report that firm risk positively affects probability of financial distress. Thus, high level of leverage is supposed to be resulted with higher probability of corporate financial distress.

Debt Maturity: Short term debt is the ratio of current debt to total debt. Long term debt is the ratio of noncurrent liabilities to overall debt. Schiantarelli and Sembenelli (1997) report that long term debt financing positively affects financial distress. The usage of long-term debt results in long run profitability of the company. However, Baum et al. (2006) demonstrate that long term debt negatively affects productivity. High repayment costs are shown as a reason for this relation. In addition, Ogundipe et al. (2012) find that using long term debt maturity advances financial performance. Since using longer term debt maturity results in excess liquidity in terms of interest- tax savings, an increase in financial performance is expected. On the other hand, Chowdhury \& Chowdhury (2010) find that short term debt financing results in lower productivity level. The working capital is normally not associated in long run profitability of the firm but for meeting recurrent expenditure. Also, use of current liabilities to finance the firm does not result in substantial interest-tax savings necessary to boost the firm's productivity. Further, according to Cuong (2014), current debt is associated with incidents of poor planning, misappropriation and misapplication due to its relative ease of access (Muigai, 2016: 105).

Tangibility: Asset tangibility is calculated by dividing fixed assets to total assets. Since tangibility reduces the level of operating cost by making higher expenditures on fixed assets, higher level of asset tangibility results in reduction of financial distress (Barton, 1988). In addition, Akintoye (2009) asserts that companies which have more tangible assets are less subject to financial distress. Because, those firms are able to maintain more sales revenue by their higher level of production. Frank and Goyal (2003) and Titman and Wessels (1988) also encapsulate this relation by showing those firms with more tangible assets as more efficient firms in production and therefore performing better (Muigai, 2016).

Firm size: Firm size is natural logarithm of total assets. Since large firms have more experience, they are expected to cope with financial distress (Lee et al., 2011). Since large firms are accepted as less risky, they have ability to borrow more at lower interest rates thus they have more debt capacity (Lee, 2009). Since large firms are able to access credit easily, they might perform well and therefore their financial distress level is lower (Muigai and Muriithi, 2017). In addition, the negative relation between firm size and cash flow volatility causes larger firms to have lower probability of financial distress (Rajan and Zingales, 1995).

Sales growth: The performance of the firms with higher sales growth is higher than those which have lower sales growth (Babalola, 2013) Thus, this positive value in performance is thought to be result in lower level of financial distress. 
Market-to-book ratio: MB is defined as the proportion of market value of equity to book value of equity. According to Campbell et al. (2011), firms with higher level of financial distress have higher market to book values.

Return on assets: Profitability of a firm is measured by return on assets which is the ratio of net income to total assets. According to Campbell et al. (2008) lower profitability results in higher level of financial distress.

\section{Results}

\subsection{Descriptive analyses}

Descriptive statistics of the dependent and independent variables are reported in Table $1 . \mathrm{Z}$ Score, leverage, return on equity, sales growth and market-to-book ratio variables are winsorized at $1 \%$ (two tail). The average $\mathrm{Z}$ Score is 7.53 and S Score is 1 . The average leverage is $48 \%$ and tangibility is at $48 \%$. Table 1 shows that Turkish firms prefer to use more short-term debt maturity (73\%) than long term debt maturity (27\%). The natural logarithm of total assets is 19.20 . The average sales growth rate is at 13.14 , average market-tobook ratio is 1.70 and average return on equity is 4.34 .

Table 1- Descriptive Statistics

\begin{tabular}{lllllll}
\hline Variable & $\mathrm{N}$ & Mean & $\mathrm{SD}$ & $\mathrm{p} 25$ & $\mathrm{p} 50$ & $\mathrm{p} 75$ \\
\hline Z Score & 1800 & 7.53 & 4.71 & 4.93 & 7.00 & 9.57 \\
S Score & 1800 & 1.01 & 0.91 & 0.45 & 0.90 & 1.41 \\
Lev & 1800 & 0.48 & 0.25 & 0.28 & 0.45 & 0.64 \\
Tang & 1800 & 0.48 & 0.19 & 0.33 & 0.48 & 0.63 \\
Ltdebt & 1800 & 0.27 & 0.18 & 0.13 & 0.24 & 0.39 \\
Stdebt & 1800 & 0.73 & 0.18 & 0.61 & 0.76 & 0.87 \\
Size & 1800 & 19.20 & 1.67 & 18.08 & 19.18 & 20.17 \\
Salesgr & 1800 & 13.14 & 26.81 & -0.37 & 10.08 & 23.98 \\
MB & 1800 & 1.70 & 1.92 & 0.68 & 1.21 & 2.04 \\
ROE & 1800 & 4.34 & 24.57 & -1.05 & 6.68 & 16.35 \\
\hline
\end{tabular}

Table 2 reports the Pearson correlation coefficients. At univariate level financial distress indicators (Z Score and S Score) are negatively correlated with leverage which is in line with the finding of Muigai (2016) who reports a positive relation between debt level and financial distress probability. In addition, leverage and tangibility variables are negatively correlated with financial distress indicators. Moreover, there is a negative correlation between long term debt ratio and S Score. Finally, S Score has positive correlations with the following variables: short term debt, firm size, sales growth rate, market-to-book ratio and ROE.

Table 2- Correlation Matrix

\begin{tabular}{lllllllllll}
\hline & Z Score & S Score & Lev & Tang & Ltdebt & Stdebt & Size & Salesgr & MB & ROE \\
\hline Z Score & 1 & & & & & & & & & \\
S Score & $0.7291^{*}$ & 1 & & & & & & & & \\
Lev & $-0.8089^{*}$ & $-0.4913^{*}$ & 1 & & & & & & & \\
Tang & $-0.1765^{*}$ & $-0.3176^{*}$ & $-0.1097^{*}$ & 1 & & & & & & \\
Ltdebt & -0.0279 & $-0.1038^{*}$ & 0.0411 & $0.4445^{*}$ & 1 & & & & & \\
Stdebt & 0.0279 & $0.1038^{*}$ & -0.0411 & $-0.4445^{*}$ & $-1.0000^{*}$ & 1 & & & & \\
Size & 0.0052 & $0.0817^{*}$ & 0.0344 & $0.2001^{*}$ & $0.2676^{*}$ & $-0.2676^{*}$ & 1 & & & \\
Salesgr & -0.006 & $0.1202^{*}$ & $0.0726^{*}$ & $-0.0976^{*}$ & -0.0406 & 0.0406 & 0.0244 & 1 & & \\
MB & 0.0393 & $0.1118^{*}$ & 0.0346 & $-0.1030^{*}$ & -0.0598 & 0.0598 & $0.0629^{*}$ & 0.0394 & 1 & \\
ROE & $0.4397^{*}$ & $0.6331^{*}$ & $-0.3503^{*}$ & $-0.1850^{*}$ & -0.0396 & 0.0396 & $0.2258^{*}$ & $0.1835^{*}$ & -0.0545 & 1 \\
\hline
\end{tabular}




\subsection{Regression Results}

Table 3 displays the results of fixed effect panel regression which test the main impact of capital structure decisions on financial distress. According to Hausman (1978) test results, null hypothesis is rejected which states that the preffered model is random effects vs the alternative the fixed effects. Thus, the firm fixed effect regressions give the most robust results. Table 3, Panel A presents the main impact of capital structure decisions on financial distress when Altman's Z Score is a dependent variable. According to the regression results, a negative relation between leverage and $Z$ Score is found. Therefore, as leverage ratio of a firm increases, its Z Score ratio decreases. Since higher Z Score is an indicator of increased financial health of a firm, the negative relation between leverage and Z-score shows that higher level of debt detorates the firm's financial health. Table 3, Panel A also shows the relation between debt maturity and financial distress of the firms. According to the results, long term debt ratio positively affects Z Score. Therefore, as maturity of debt increases the financial health of the firms increases. Furthermore, the firm specific characteristics seem to be effective on financial distress level of the firms. Profitability and firm size have positive relation with $Z$ Score. In contrast, tangibility has a negative relation with Z Score.

Table 3, Panel B, presents the relation between capital structure decisions and financial distress by using $\mathrm{S}$ Score as dependent variable. According to Panel B, a negative relation between leverage and S Score occurs. In addition, as long-term debt increases the $S$ Score increases. Therefore, similar results are found with Panel A. The only difference is the significance of market-to-book ratio. Although there is not any significant relation between MB and Z Score in Panel A, a positively significant relation is found in Panel B between these variables.

Table 3- The Impact of Capital Structure on Financial Distress

\begin{tabular}{lllll}
\hline & Panel A & & Panel B & \\
\hline & 1 & 2 & 3 & 4 \\
\hline Lev & Z Score & Z Score & S Score & S Score \\
& & & & \\
Ltdebt & $-14.71^{* * *}$ & $-14.71^{* * *}$ & $-1.260^{* * *}$ & $-1.260^{* * *}$ \\
& $(-15.47)$ & $(-15.47)$ & $(-5.84)$ & $(-5.84)$ \\
Stdebt & $4.640^{* * *}$ & & $1.160^{*}$ & \\
& $(7.76)$ & & $(2.28)$ & $-1.160^{*}$ \\
Size & & $-4.640^{* * *}$ & & $(-2.28)$ \\
& & $(-7.76)$ & & -0.268 \\
Salesgr & $0.57^{*}$ & $0.57^{*}$ & -0.268 & $(-1.32)$ \\
& $(1.79)$ & $(1.79)$ & $(-1.32)$ & 0.00496 \\
MB & & & & $(1.49)$ \\
& 0.00343 & 0.00343 & 0.00496 & $0.0281^{*}$ \\
ROE & $(1.11)$ & $(1.11)$ & $(1.49)$ & $(1.7)$ \\
& 0.0652 & 0.0652 & $0.0281^{*}$ & $0.0132^{* * *}$ \\
Tang & $(1.58)$ & $(1.58)$ & $(1.7)$ & $(6.22)$ \\
& $0.00859^{* *}$ & $0.00859^{* *}$ & $0.0132^{* * *}$ & $-2.301^{* * *}$ \\
_cons & $(2.98)$ & $(2.98)$ & $(6.22)$ & $(-8.53)$ \\
& $-9.464^{* * *}$ & $-9.464^{* * *}$ & $-2.301^{* * *}$ & $8.587^{*}$ \\
N & $(-11.96)$ & $(-11.96)$ & $(-8.53)$ & $(1.99)^{* *}$ \\
\hline & 6.184 & 10.82 & $7.428^{*}$ & 1800 \\
\hline
\end{tabular}


Table 4 and Table 5 demonstrate the effect of firm characteristics on the relation between capital structure and financial distress. Table 4 uses $\mathrm{Z}$ Score as a dependent variable, whereas Table 5 uses S Score as a dependent variable. To consider the firm charateristics, an interaction term is created with each firm characteristics and capital structure variables. For instance, Lev*size is an interaction term which is created with leverage and firm size, LT $^{*}$ size is created with long term debt and firm size.

Table 4 shows that both lev*size and LT*size are not significant. Therefore, firm size is not effective on the relation between financial distress and capital structure. Similarly, this relation is not affected by tangibility, sales growth and market-to-book ratio. However, the interaction terms created with ROE have significant relations with $\mathrm{Z}$ Score. The negative coefficient of $\operatorname{lev}^{*} \mathrm{ROE}$ indicates that increasing debt among the firms with higher profitability reduces $Z$ Score thus increases financial distress. Furthermore, $\mathrm{LT}^{*} \mathrm{ROE}$ interaction term also has a negative relation with $Z$ Score. This shows that increasing long term debt ratio among the firms with higher profitability reduces $Z$ Score.

Table 5 includes surprising results. Firstly, lev*size interaction term has a negative relation with S Score which means that increasing debt among the large firms reduces S Score. The positive constant of lev*tang variable demonstrates that among firms with high tangibility increased leverage results in higher S Score. On the other hand, the negative constant of $\mathrm{LT}^{*}$ tang shows that increasing long term debt ratio among the tangible firms reduces Z Score. Finally, the negative relation between lev*ROE and S Score shows that increased leverage among high profitability firms results in lower S Score.

Table 4- Panel Regression Results with Z Score

\begin{tabular}{|c|c|c|c|c|c|c|c|c|c|c|}
\hline & $\begin{array}{l}(1) \\
\text { Z Score }\end{array}$ & $\begin{array}{l}\text { (2) } \\
\text { Z Score }\end{array}$ & $\begin{array}{l}\text { (3) } \\
\text { Z Score }\end{array}$ & $\begin{array}{l}\text { (4) } \\
\text { Z Score }\end{array}$ & $\begin{array}{l}\text { (5) } \\
\text { Z Score }\end{array}$ & $\begin{array}{l}\text { (6) } \\
\text { Z Score }\end{array}$ & $\begin{array}{l}\text { (7) } \\
\text { Z Score }\end{array}$ & $\begin{array}{l}\text { (8) } \\
\text { Z Score }\end{array}$ & $\begin{array}{l}\text { (9) } \\
\text { Z Score }\end{array}$ & $\begin{array}{l}(10) \\
\text { Z Score }\end{array}$ \\
\hline Lev*size & $\begin{array}{l}0.26 \\
(0.54)\end{array}$ & & & & & & & & & \\
\hline $\mathrm{LT}^{*}$ size & & $\begin{array}{l}-0.0165 \\
(-0.04)\end{array}$ & & & & & & & & \\
\hline Lev*tang & & & $\begin{array}{l}1.914 \\
(0.75)\end{array}$ & & & & & & & \\
\hline $\mathrm{LT}^{*} \operatorname{tang}$ & & & & $\begin{array}{l}-0.993 \\
(-0.45)\end{array}$ & & & & & & \\
\hline Lev*sales & & & & & $\begin{array}{l}0.0216 \\
(1)\end{array}$ & & & & & \\
\hline $\mathrm{LT}^{*}$ sales & & & & & & $\begin{array}{l}0.011 \\
(0.84)\end{array}$ & & & & \\
\hline $\mathrm{Lev}^{*} \mathrm{mb}$ & & & & & & & $\begin{array}{l}0.145 \\
(1.27)\end{array}$ & & & \\
\hline $\mathrm{LT}^{*} \mathrm{mb}$ & & & & & & & & $\begin{array}{l}0.276 \\
(1.23)\end{array}$ & & \\
\hline $\mathrm{Lev}^{*} \mathrm{ROE}$ & & & & & & & & & $\begin{array}{l}-0.0986^{* * *} \\
(-8.97)\end{array}$ & \\
\hline $\mathrm{LT}^{*} \mathrm{ROE}$ & & & & & & & & & & $\begin{array}{l}-0.0218^{*} \\
(-2.14)\end{array}$ \\
\hline Lev & $\begin{array}{l}-19.51^{*} \\
(-2.09)\end{array}$ & $\begin{array}{l}-14.70^{* * *} \\
(-14.87)\end{array}$ & $\begin{array}{l}-15.66^{* * *} \\
(-11.71)\end{array}$ & $\begin{array}{l}-14.71^{* * *} \\
(-15.50)\end{array}$ & $\begin{array}{l}-14.98^{* * *} \\
(-14.76)\end{array}$ & $\begin{array}{l}-14.71^{* * *} \\
(-15.42)\end{array}$ & $\begin{array}{l}-14.95^{* * *} \\
(-14.41)\end{array}$ & $\begin{array}{l}-14.72^{* * *} \\
(-15.67)\end{array}$ & $\begin{array}{l}-14.46^{* * *} \\
(-15.90)\end{array}$ & $\begin{array}{l}-14.66^{* * *} \\
(-15.44)\end{array}$ \\
\hline LTdebt & $\begin{array}{l}4.602^{* * *} \\
(7.6)\end{array}$ & $\begin{array}{l}4.953 \\
(0.61)\end{array}$ & $\begin{array}{l}4.677^{* * *} \\
(7.82)\end{array}$ & $\begin{array}{l}5.158^{* * *} \\
(4.27)\end{array}$ & $\begin{array}{l}4.606^{* * *} \\
(7.85)\end{array}$ & $\begin{array}{l}4.513^{* * *} \\
(8.41)\end{array}$ & $\begin{array}{l}4.647^{* * *} \\
(7.75)\end{array}$ & $\begin{array}{l}4.164^{* * *} \\
(5.23)\end{array}$ & $\begin{array}{l}4.675^{* * *} \\
(8.12)\end{array}$ & $\begin{array}{l}4.603^{* * *} \\
(7.74)\end{array}$ \\
\hline Size & $\begin{array}{l}0.396 \\
(0.97)\end{array}$ & $\begin{array}{l}0.575^{*} \\
(1.76)\end{array}$ & $\begin{array}{l}0.565^{*} \\
(1.77)\end{array}$ & $\begin{array}{l}0.574^{*} \\
(1.81)\end{array}$ & $\begin{array}{l}0.561 \\
(1.76)\end{array}$ & $\begin{array}{l}0.567^{*} \\
(1.77)\end{array}$ & $\begin{array}{l}0.546^{*} \\
(1.71)\end{array}$ & $\begin{array}{l}0.568^{*} \\
(1.78)\end{array}$ & $\begin{array}{l}0.614^{*} \\
(2.01)\end{array}$ & $\begin{array}{l}0.586^{*} \\
(1.84)\end{array}$ \\
\hline Tang & $\begin{array}{l}-9.459^{* * *} \\
(-11.93)\end{array}$ & $\begin{array}{l}-9.460^{* * *} \\
(-12.00)\end{array}$ & $\begin{array}{l}-10.45^{* * *} \\
(-6.92)\end{array}$ & $\begin{array}{l}-9.210^{* * *} \\
(-7.87)\end{array}$ & $\begin{array}{l}-9.396^{* * *} \\
(-11.73)\end{array}$ & $\begin{array}{l}-9.465^{* * *} \\
(-11.95)\end{array}$ & $\begin{array}{l}-9.485^{* * *} \\
(-12.07)\end{array}$ & $\begin{array}{l}-9.464^{* * *} \\
(-12.07)\end{array}$ & $\begin{array}{l}-8.731^{* * *} \\
(-11.89)\end{array}$ & $\begin{array}{l}-9.420^{* * *} \\
(-12.00)\end{array}$ \\
\hline Salesgr & $\begin{array}{l}0.00345 \\
(1.11)\end{array}$ & $\begin{array}{l}0.00342 \\
(1.13)\end{array}$ & $\begin{array}{l}0.00354 \\
(1.16)\end{array}$ & $\begin{array}{l}0.00341 \\
(1.11)\end{array}$ & $\begin{array}{l}-0.00801 \\
(-0.80)\end{array}$ & $\begin{array}{l}0.000724 \\
(0.29)\end{array}$ & $\begin{array}{l}0.00349 \\
(1.13)\end{array}$ & $\begin{array}{l}0.00345 \\
(1.11)\end{array}$ & $\begin{array}{l}0.00232 \\
(0.78)\end{array}$ & $\begin{array}{l}0.00346 \\
(1.11)\end{array}$ \\
\hline $\mathrm{Mb}$ & $\begin{array}{l}0.0613 \\
(1.51)\end{array}$ & $\begin{array}{l}0.0652 \\
(1.58)\end{array}$ & $\begin{array}{l}0.0674^{*} \\
(1.67)\end{array}$ & $\begin{array}{l}0.0644 \\
(1.58)\end{array}$ & $\begin{array}{l}0.0669 \\
(1.61)\end{array}$ & $\begin{array}{l}0.0643 \\
(1.56)\end{array}$ & $\begin{array}{l}-0.037 \\
(-0.52)\end{array}$ & $\begin{array}{l}-0.0073 \\
(-0.12)\end{array}$ & $\begin{array}{l}0.0166 \\
(0.46)\end{array}$ & $\begin{array}{l}0.0688^{*} \\
(1.66)\end{array}$ \\
\hline
\end{tabular}


N. Abdioğlu 11/2 (2019) 1057-1067

\begin{tabular}{lllllllllll} 
ROE & $0.00860^{* *}$ & $0.00861^{* *}$ & $0.00848^{* *}$ & $0.00862^{* *}$ & $0.00800^{*}$ & $0.00859^{* *}$ & $0.00897^{* *}$ & $0.00824^{* *}$ & $0.0808^{* * *}$ & $0.0140^{* * *}$ \\
& $(2.97)$ & $(2.94)$ & $(3.03)$ & $(2.98)$ & $(2.57)$ & $(2.96)$ & $(3.19)$ & $(2.92)$ & $(9.05)$ & $(3.75)$ \\
_cons & 9.459 & 6.085 & 6.761 & 5.987 & 6.495 & 6.276 & 6.845 & 6.357 & 4.668 & 5.831 \\
& $(1.2)$ & $(0.94)$ & $(1.09)$ & $(0.97)$ & $(1.05)$ & $(1.01)$ & $(1.1)$ & $(1.03)$ & $(0.79)$ & $(0.94)$ \\
& & & & & & & & & \\
N & 1800 & 1800 & 1800 & 1800 & 1800 & 1800 & 1800 & 1800 & 1800 & 1800 \\
\hline
\end{tabular}

Table 5- Panel Regression Results with S Score

\begin{tabular}{|c|c|c|c|c|c|c|c|c|c|c|}
\hline & $(1)$ & $(2)$ & (3) & (4) & (5) & (6) & (7) & (8) & (9) & (10) \\
\hline & S Score & S Score & S Score & S Score & S Score & S Score & S Score & S Score & S Score & S Score \\
\hline \multirow[t]{2}{*}{ Lev*size } & $-0.477^{* *}$ & & & & & & & & & \\
\hline & $(-2.86)$ & & & & & & & & & \\
\hline \multirow[t]{2}{*}{$\mathrm{LT}^{*}$ size } & & 0.0957 & & & & & & & & \\
\hline & & $(0.58)$ & & & & & & & & \\
\hline \multirow[t]{2}{*}{ Lev*tang } & & & $1.788^{* *}$ & & & & & & & \\
\hline & & & (1.94) & & & & & & & \\
\hline \multirow[t]{2}{*}{ LTtang } & & & & $-2.716^{*}$ & & & & & & \\
\hline & & & & $(-1.74)$ & & & & & & \\
\hline \multirow[t]{2}{*}{ Lev*sales } & & & & & 0.0262 & & & & & \\
\hline & & & & & $(0.96)$ & & & & & \\
\hline \multirow[t]{2}{*}{$\mathrm{LT}^{*}$ sales } & & & & & & 0.00734 & & & & \\
\hline & & & & & & $(0.85)$ & & & & \\
\hline \multirow[t]{2}{*}{$\operatorname{Lev}^{*} \mathrm{mb}$} & & & & & & & 0.0992 & & & \\
\hline & & & & & & & $(1.25)$ & & & \\
\hline \multirow[t]{2}{*}{$\mathrm{LT}^{*} \mathrm{mb}$} & & & & & & & & -0.0733 & & \\
\hline & & & & & & & & $(-0.50)$ & & \\
\hline \multirow[t]{2}{*}{$\mathrm{Lev}^{*} \mathrm{ROE}$} & & & & & & & & & $-0.0786^{* * *}$ & \\
\hline & & & & & & & & & $(-7.66)$ & \\
\hline \multirow[t]{2}{*}{$\mathrm{LT}^{*} \mathrm{ROE}$} & & & & & & & & & & 0.00488 \\
\hline & & & & & & & & & & -0.71 \\
\hline \multirow[t]{2}{*}{ Lev } & $7.521^{*}$ & $-1.288^{* * *}$ & $-2.149^{* * *}$ & $-1.256^{* * *}$ & $-1.592^{* * *}$ & $-1.258^{* * *}$ & $-1.427^{* * *}$ & $-1.256^{* * *}$ & $-1.065^{* * *}$ & $-1.270^{* * *}$ \\
\hline & $(2.48)$ & $(-6.93)$ & $(-4.62)$ & $(-5.98)$ & $(-3.36)$ & $(-5.76)$ & $(-5.57)$ & $(-5.85)$ & $(-5.55)$ & $(-5.92)$ \\
\hline \multirow[t]{2}{*}{ LTdebt } & $1.229^{*}$ & -0.652 & $1.194^{*}$ & $2.578^{* *}$ & $1.119^{* *}$ & $1.075^{*}$ & $1.165^{* *}$ & $1.286^{*}$ & $1.188^{*}$ & $1.168^{*}$ \\
\hline & $(2.36)$ & $(-0.18)$ & $(2.38)$ & $(2.21)$ & $(2.61)$ & $(2.45)$ & $(2.28)$ & (1.8) & (2.39) & (2.3) \\
\hline \multirow[t]{2}{*}{ Size } & 0.0514 & $-0.297^{*}$ & -0.272 & -0.257 & -0.28 & -0.27 & -0.285 & -0.268 & -0.233 & -0.271 \\
\hline & $(0.37)$ & $(-1.67)$ & $(-1.35)$ & $(-1.31)$ & $(-1.44)$ & $(-1.32)$ & $(-1.40)$ & $(-1.33)$ & $(-1.17)$ & $(-1.33)$ \\
\hline \multirow[t]{2}{*}{ Tang } & $-2.309^{* * *}$ & $-2.323^{* * *}$ & $-3.222^{* * *}$ & $-1.606^{* * *}$ & $-2.219^{* * *}$ & $-2.302^{* * *}$ & $-2.315^{* * *}$ & $-2.301^{* * *}$ & $-1.717^{* * *}$ & $-2.311^{* * *}$ \\
\hline & $(-8.60)$ & $(-8.84)$ & $(-5.23)$ & $(-3.50)$ & $(-8.36)$ & $(-8.46)$ & $(-8.44)$ & $(-8.50)$ & $(-7.82)$ & $(-8.56)$ \\
\hline \multirow[t]{2}{*}{ Salesgr } & 0.00493 & 0.005 & 0.00507 & 0.00492 & -0.00891 & 0.00316 & 0.005 & 0.00496 & 0.00408 & 0.00495 \\
\hline & (1.5) & $(1.52)$ & $(1.53)$ & (1.49) & $(-0.76)$ & $(1.48)$ & (1.5) & (1.5) & $(1.22)$ & (1.49) \\
\hline \multirow[t]{2}{*}{ MB } & $0.0353^{*}$ & $0.0279^{*}$ & $0.0301^{*}$ & $0.026^{*}$ & $0.0302^{*}$ & $0.0275^{*}$ & -0.0416 & 0.0474 & -0.0106 & $0.0273^{*}$ \\
\hline & $(2.13)$ & $(1.66)$ & $(1.85)$ & $(1.64)$ & $(1.75)$ & $(1.67)$ & $(-0.64)$ & $(0.99)$ & $(-0.74)$ & (1.66) \\
\hline \multirow[t]{2}{*}{ ROE } & $0.0132^{* * *}$ & $0.0131^{* * *}$ & $0.0131^{* * *}$ & $0.0132^{* * *}$ & $0.0125^{* * *}$ & $0.0132^{* * *}$ & $0.0134^{* * *}$ & $0.0133^{* * *}$ & $0.0707^{* * *}$ & $0.0120^{* * *}$ \\
\hline & $(6.22)$ & $(6.35)$ & $(6.25)$ & $(6.32)$ & $(4.97)$ & $(6.23)$ & $(6.29)$ & $(6.56)$ & $(8.31)$ & $(4.01)$ \\
\hline \multirow[t]{2}{*}{ _cons } & 1.434 & $8.002^{*}$ & $7.967^{*}$ & $6.889^{*}$ & $7.804^{*}$ & $7.489^{*}$ & $7.878^{*}$ & $7.381^{*}$ & $6.22^{*}$ & $7.507^{*}$ \\
\hline & $(0.54)$ & $(2.35)$ & (2.13) & (1.9) & $(2.02)$ & (1.9) & $(2.02)$ & $(1.94)$ & $(1.62)$ & (1.92) \\
\hline $\mathrm{N}$ & 1800 & 1800 & 1800 & 1800 & 1800 & 1800 & 1800 & 1800 & 1800 & 1800 \\
\hline
\end{tabular}




\section{Conclusions and Discussion}

In this paper, the relation between capital structure decisions and corporate financial distress of Turkish firms is firstly examined. The findings indicate that increased debt usage causes higher financial distress level. This outcome is in accordance with Trade-Off Theory which states that an optimal level of debt should be determined by the companies. Although debt usage has tax advantages, higher amount of debt causes financial distress. Moreover, the results support that increased amount of short-term debt maturity results in higher financial distress. Usage of long-term debt increases liquidity in terms of tax- savings and firm performance increases (Ogundipe et al., 2012). Positive relation between financial success and size, market to book ratio and ROE are reported. In contrast, it is found that as asset tangibility in a firm increases, the financial distress level increases.

Secondly, it is researched that how effective the firm characteristics on the association between financial distress and capital structure. The relation between capital structure and financial distress is affected by ROE, firm size and tangibility variables. The findings show that increasing debt among higher profitability firms increases financial distress level. Being more profitable does not give priority to the firms in terms of using more debt. As the debt level of those firms increase, the financial distress levels increase. Furthermore, increasing debt among large firms results in higher financial distress level for Turkish firms. This finding is in contrast with finding of Muigai and Muriithi (2017) who examine this relation for Kenyan firms. Therefore, being large in size do not change the relation between leverage and financial distress for Turkish listed firms. Increased leverage results in higher level of financial distress. Moreover, increasing debt among firms with more tangible assets results in higher financial success. Tangibility seems to reduce the negative impact of debt on financial success. Since those firms can maintain more sales revenue by their higher level of production, they are less subject to financial distress. This feature of those firms seems to be effective in our results.

Finally, it is investigated that how the association between debt maturity and financial distress is affected by firm charateristics. ROE and tangibility variables are found to be effective on this relation. It is reported that increasing long term debt ratio among higher profitability firms increases financial distress. Therefore, those companies should choose more short-term debt so as to decrease financial distress levels. Moreover, the analyses show that increasing long-term debt ratio among firms with more tangible assets increases financial distress level.

In sum, this paper contributes to the financial distress literature by finding impacts of profitability, firm size and tangibility on the relation between capital structure and financial distress. Future research could examine this relation for different industries with different firm specific characteristics.

\section{References}

Akintoye, I. R. (2009). Sensitivity of Performance to Capital Structure. Banking and Finance Letters, 1(1), 29.

Akpınar, O. and Akpınar, G. (2017). Finansal Başarısızlık Riskinin Belirleyicileri: Borsa İstanbul'da Bir Uygulama. İşletme Araştırmaları Dergisi, 9(4), 932-951.

Aktaş, R., Doğanay, M. and Yıldız, B. (2003). Mali Başarısızlığın Öngörülmesi: İstatistiksel Yöntemler ve Yapay Sinir Ağı Karşılaştırması. Ankara Üniversitesi Siyasal Bilgiler Fakültesi Dergisi, 58(4), 1-24.

Altman, E. I. (1968). Financial Ratios, Discriminant Analysis and the Prediction of Corporate Bankruptcy. The Journal of Finance, 23(4), 589-609.

Ayan, T. Y. and Değirmenci, N. (2018). Firma Finansal Başarısızlık Öngörüsü için Bir Lojistik Regresyon Modeli. UIIİD-IJEAS, 18. EYİ Özel Sayısı, 77-88.

Babalola, Y. A. (2013). The effect of firm size on firms profitability in Nigeria. Journal of Economics and Sustainable Development, 4(5), 90-94.

Barton, S.L., 1988. Diversification strategy and systematic risk: another look. Academy of Management Journal, 31 (1), 166-175. 
Baum, C. F., Schafer, D., and Talavera, O. (2006). The Effects of Short-Term Liabilities on Profitability: A Comparison of German and US Firms (Vol. 636). Boston College Working Papers in Economics.

Berger, A. N., and Di Patti, E. B. (2006). Capital structure and firm performance: A new approach to testing agency theory and an application to the banking industry. Journal of Banking \& Finance, 30(4), 10651102.

Brealey, R. A., and Myers, S. C. (2006). Principles of Corporate Finance (Wall Street Edition): New York: McGraw-Hill.

Campbell J.Y., Hilscher, J., and Szilagyi, J. (2008). In search of distress risk. Journal of Finance, 63, 2899- 2939.

Campbell, J.Y., Hilscer, J. and Szilagyi, J. (2011). Predicting Financial Distress and the Performance of Distressed Stocks. Journal of Investment Management, 9(2), 1-21.

Chancharat, N. (2008). An empirical analysis of financially distressed Australian companies: The application of survival analysis. Dissertation of Doctor of Philosophy School of Accounting and Finance-Faculty of Commerce, University of Wollongong, http://ro.uow.edu.au/theses/401, 1-259.

Chou,H-I., Li, H., and Yin, X. (2010). The effects of financial distress and capital structure on the work effort of outside directors. Journal of Empirical Finance, 17 (3), 300-312.

Chowdhury, A., and Chowdhury, S. P. (2010). Impact of capital structure on firm "s value: Evidence from Bangladesh. Business and Economic Horizons, 3(3), 111-122.

Cuong, N. T. (2014). Threshold effect of capital structure on firm value: Evidence from seafood processing enterprises in the South Central region of Vietnam. International Journal of Finance \& Banking Studies, 3(3), 14-29.

Ege, İ., Topaloğlu, E. E. and Erkol, A. Y. (2017). Fulmer Modeline Dayalı Finansal Başarısızlık ile Finansal Performans İlişkisi: İmalat Sanayi Üzerine Bir Uygulama. Muhasebe ve Finansman Dergisi, Nisan, 119-137.

Frank, M. Z., and Goyal, V. K. (2003). Testing the pecking order theory of capital structure. Journal of Financial Economics, 67(2), 217-248.

Gujarati, D.N., 2004. Basic Econometrics. The McGraw-Hill Companies.

Gupta, P., Srivastava, A., and Sharma, D. (2014). Capital structure and financial performance: Evidence from India. International Research Journal, 2(6), 112-126.

Hadlock, C. J., and James, C. M. (2002). Do banks provide financial slack? The Journal of Finance, 57(3), 13831419.

Hausman, J.A., 1978. Specification Tests in Econometrics. Econometrica. 46, 1251- 1271.

Lee, S., Koh, Y., and Kang, K. H. (2011). Moderating effect of capital intensity on the relationship between leverage and financial distress in the U.S. restaurant industry. International Journal of Hospitality Management. 30(2), 429-438.

Lubatkin, M. And Chatterjee, S., 1994. Extending modern portfolio theory into the domain of corporate diversification: does it apply? The Academy of Management Journal, 37 (1), 109-136.

Mandelker, G.N. and Rhee, S.G., 1984. The impact of the degrees of operating and financial leverage on systematic risk of common stock. The Journal of Finance and Quantitative Analysis, 79 (1), 45-57.

Muigai, R. G. (2016). Effect of capital structure on financial distress of non-financial companies listed in Nairobi securities exchange. Dissertation of Doctor of Philosophy in Finance in the Jomo Kenyatta University of Agriculture and Technology.

Muigai, R.G. and Muriithi, J.G. (2017). The Moderating Effect of Firm Size on the Relationship Between Capital Structure and Financial Distress of Non-Financial Companies Listed in Kenya. Journal of Finance and Accounting. 5(4), 151-158 
Muigai, R.G. and Mutiso, A.N. (2018). The Moderating Effect of the Listing Sector on the Relationship Between Capital Structure and Financial Distress of Non-Financial Companies Listed in Kenya. Research Journal of Finance and Accounting, 9(6), 139-146.

Myers, S.C. (1977). Determinants of corporate borrowing. Journal of Financial Economics, 5(2), 147-175.

Ogundipe, O., Ogundipe, E., \&Ajao, K. (2012). Cash Holding and Firm Characteristics:

Evidence from Nigerian Emerging Market. Journal of Business, Economics \& Finance

Ogundipe, O., Ogundipe, E., \&Ajao, K. (2012). Cash Holding and Firm Characteristics:

Evidence from Nigerian Emerging Market. Journal of Business, Economics \& Finance

Ogundipe, O., Ogundipe, E., and Ajao, K. (2012). Cash Holding and Firm Characteristics: Evidence from Nigerian Emerging Market. Journal of Business, Economics \& Finance, 1, (2), 2146-7943.

Opler, T.C. and S. Titman (1994), Financial Distress and Corporate Performance. Journal of Finance, 49, 10151040.

Ozcalik, S.G. and Aytekin, S. (2018). Fulmer Modelinin Belirleyicileri: Finansal Performans Açısından Bir Değerlendirme. Uluslararası İktisadi ve İdari İncelemeler Dergisi. 17. UİK Özel Sayısı, 281-292.

Peterson, M.A., 1994. Cash flow variability and firm's pension choice: a role for operating leverage. Journal of Financial Economics, 36, 361-383.

Pindado, J. and Rodrigues, L., 2005. Determinants of financial distress costs. Financial Markets and Portfolio Management, 19 (4), 343-359.

Pindado, J., Rodrigues, L. De la Torre, C., 2008. Estimating financial distress likelihood. Journal of Business Research, 61, 995-1003.

Pushner, G. M. (1995). Equity ownership structure, leverage, and productivity: Empirical evidence from Japan. Pacific-Basin Finance Journal, 3(2), 241-255.

Rajan, R. G., and Zingales, L. (1995). What do we know about capital structure? Some evidence from international data. The Journal of Finance, 50(5), 1421-1460.

Schiantarelli, F., and Sembenelli, A. (1997). The maturity structure of debt; determinants and effects on firms' performance: Evidence from the United Kingdom and Italy (January 1997). World Bank Policy Research Working Paper (1699).

Tan, T. K. (2012). Financial Distress and Firm Performance: Evidence from the Asian Financial Crisis. Journal of Finance and Accountancy, 11(10), 1-11.

Terzi, S. (2011). Finansal Rasyolar Yardımıyla Finansal Başarısızlık Tahmini: Gıda Sektöründe Ampirik Bir Araştırma. Çukurova Üniversitesi İ̈BF Dergisi, 15(1), 1-18.

Thim, C.K., Choong, Y.V. and Nee, C.S. (2011). Factors Affecting Financial Distress: The Case of Malaysian Public Listed Firms. Corporate Ownership \& Control , 8(4), 345-351.

Titman, S., and Wessels, R. (1988). The determinants of capital structure choice. The Journal of Finance, 43(1), $1-19$.

Turaboglu, T.T., Erkol, A.Y. and Topaloglu, E.E., 2017. Finansal Başarısızlık ve Sermaye Yapısı Kararları: BIST 100 Endeksindeki Firmalar Üzerine Bir Uygulama. Business and Economics Research Journal, 8 (2), 247-258.

Umar, M., Tanveer, Z., Aslam, S., and Sajid, M. (2012). Impact of capital structure on firms' financial performance: Evidence from Pakistan. Research Journal of Finance and Accounting, 3(9), 1-12.

Wu, D., Liang, L. And Yang, Z., 2008. Analyzing the financial distress of Chinese public companies using probabilistic neural networks and multivariate discriminate analysis. Socio-Economic Planning Sciences, 42 (3), 206-220. 
N. Abdioğlu 11/2 (2019) 1057-1067

Zulkarnain, M. S. and Shamsher, M. (2004). Assessing corporate financial distress in Malaysia". In "Regional financial markets". 